TEME, г. XLI, бр. 4, октобар - децембар 2017, стр. 1145-1148

Приказ дела

DOI: $10.22190 /$ TEME1704145M

Примљено: 14. 12. 2017.

Одобрено за штампу: 15. 12. 2017.

\title{
О МУЛТИКУЛТУРАЛНОСТИ У НАУЧНОМ ОГЛЕДАЛУ *
}

\author{
Јордана С. Марковић \\ Универзитет у Нишу, Филозофски факултет, Ниш, Србија \\ jordana.markovic@filfak.ni.ac.rs
}

Трећу годину заредом из штампе излази часопис Исходишта, који је плод сарадње Филозофског факултета из Ниша, Савеза Срба у Румунији (Центра за научна истраживања и културу Срба у Румунији) и Филолошког, историјског и теолошког факултета Западног универзитета у Темишвару. Часопис је посвећен Материјалној и духовној култури Срба у мултиетничким срединама и/или периферним областима и то је и назив научних скупова који се почев од 2014. године сваке године наизменично одржавају у Темишвару (где је одржан први) и Нишу. Октобра ове године одржан је четврти такав скуп на Филозофском факултету у Нишу.

Трећи број овог часописа штампан је 2017. године и у њему се претежно налазе радови учесника трећег таквог скупа, одржаног октобра 2016. године у Темишвару.

У часопису се налазе 43 рада са 45 аутора. Аутори тих радова су из различитих институција у Румунији и Србији.

У својим радовима више аутора бави се народним говорима на тлу Румуније. Жарко Бошњаковић анализира творбу футура I у српским поморишким говорима у Румунији, Гордана Драгин говори о акценту на примерима из говора Чакова, како и гласи наслов њеног рада, а тој тематици посвећен је и рад Александре Лончар Раичевић $O$ акценатским карактеристикама српских говора у Румунији (говор Дињаша). Зоран Симић у раду $O$ темпоралним предлошко-падежним формама у говору Банатске Црне Горе даје свој допринос опису народних говора Срба у Румунији. Њима се придружује и Драгана Радовановић радом Теренски записи из Ченеја. У свим овим радовима анализи је подвргнут живи српски народни говор до којег се дошло обиласком терена и бележењем аутентичне грађе. Веома је значајно да се овај посао обави док још има добрих информатора.

\footnotetext{
* Исходишта 3, Темишвар/Ниш: Савез Срба у Румунији, Центар за научна истраживања и културу Срба у Румунији, Филозофски факултет Универзитета у Нишу, Филолошки, историјски и теолошки факултет Западног универзитета у Темишвару, 2017. (Главни и одговорни уредник проф. др Михај (Миља) Радан).
} 
Језику књижевних дела такође је посвећено више радова. Неки од њих баве се анализом књижевног дела на специфичан начин, указујући само на одређени сегмент, док други дају осврт на поједине језичке сегменте у језику одређеног књижевног дела.

Снежана Милојевић у раду Релативизащија појма овде и тамо, свој и туђи у Доментијановом Животу Светога Саве приближава једно прошло време и једног писца из старије епохе, осветљујући га на специфичан начин, а Горан Максимовић у раду Комичне поуке Доситеја Обрадовића даје осврт на хумористички аспект Доситејевих поука.

Бојана Вељовић у раду Обележавање прошлих понављаних радњи у приповеткама Ћамила Сијарића упознаје читаоце са језичким карактеристикама писца са другог српског језичког простора показујући његове специфичности. У раду Говор ликова и говор приповедача у завичајној прози Добрила Ненадића (лингвостилистички аспект) Милка Николић указује на језичке карактеристике јунака и приповедача, а аутори Радоје Симић и Јелена Јовановић Симић говоре о Улози дијалектизама и локализама у српској књижевности доба реализма, на шта се надовезују и радови Саве Стаменковића Политика и дијалект: Иван Ивановић, шопски говор и приповетке из циклуса „Север-југ” и Тање Танасковић Лексичке позајмљенице у прози на дијалекту Драгослава Михаиловића.

Своје место нашла је и музика. Музичком темом бави се ауторка Марија Думнић у раду Носталгија у интерпретацији тамбурашких оркестара у Темишвару 2016. године: староградска музика и тамбураштво.

Више радова посвећено је етнолингвистичкој проблематици. Аутор Љубица Ђурић анализира податке са српског гробља у раду Контекстуализација језичких пејзажа српских гробова у региону реке Мориша. Допринос истраживању српских народних обичаја пружају радови: Породична слава код Срба у Румунији - Дињаш и Ченеј Малине Ивановић Баришић, Етнографија намењивања плеса покојнику у селу Свиници ауторке Селене Ракочевић, рад Традиционната сватба от северен Банат (Сьрбия) и свтбата на банатските бьлгари - сравнително иследване Веселке Тончеве, Карашевска свадба данас - обичаји, ритуали и нихова значења (симболика) Миљане-Радмиле Радан Ускату, а информације о таквим истраживањима доноси и рад Ивице Тодоровића О новим етнолошким истраживањима Срба у Румунији.

Тој тематици придружио се и Видан Николић у раду Дистрибуциија микротопонима Сватовско гробље на српско (хрватском) језичком подручју (ономастички и етнолингвистички аспект).

Знаменитим личностима из историје Срба у Румунији посвећени су радови: Саше Јашина Епископ темишварски Петар Пелеменити Петровић (1786-1800), Живе Милина Темишварски слависта Чезар Апреотесеј и његови радови о румунско-српским културним везама.

Радове у којима се говори о приморским крајевима доносе аутори Ирена Арсић (Од Орбина до Стојановића: словинство Дубровчана кроз векове) и Владимир Рогановић (Барокни песник Живо Болица и почеци књижевности на народном језику у Боки Которској у XVII веку).

Дијалекатском лексикографијом на грађи из српских говора у Румунији баве се аутори Бранкица Марковић у раду Из терминологије овчарства села Рудне у Румунији, Михај Радан у раду $O$ пореклу карашевске ко- 
вачке терминологије у говорима Карамева и Клокотича, Татјана Трајковић у раду Ратарска терминологија села Рудне у Румунији.

Лексикографије се тичу и радови Снежане Гудурић $O$ неколиким особеним франиуским траговима у српском и Рајне Драгићевић Лексикографски трагови језичких и културолошких контаката Срба са другим народима у ХІХ веку.

Граничним областима посвећени су радови: Чеси на банатској војној граници у првој половини 19. века аутора Вацлава Штепанека, Этнический активизм Румын (Влахов) восточной Сербии Наталије Голант, $18^{\text {th }}$ century Serbian architectural principles in the former provinces of the Habsburg empire, a case study on Banat and Hungary Михаеле Власцеану, Защь Карашовените не са Бьлгари, чији је аутор Николае Марков, Последице међујезичког контакта на фонолошко-фонетском плану у српским говорима југозападног дела Косова и Метохије Радивоја Младеновића.

Статусу српског језика и стањем тога језика у Румунији баве се следећи аутори: Биљана Сикимић у раду Видљивост карашевског говора у јавном простору, Срето Танасић, О синтакси листа „Наша реч”, Светлана Ћирковић, Настава на српском језику у Поморишју данас.

Међу бројним областима своје место нашла је и ономастика у радовима: Саше Митровића Деривација српских мушких имена у Дунавској клисури и Благоја Чоботина Имена српске деце критене у Српској православној иркви у Кетфељу током XIX, XX и ХХІ века.

Изучавању културних прилика свој допринос дао је Иван Бирта у раду Духовна култура Срба у румунском Банату (18. век), а сличне тематике су и радови Октавије Неделку и Лидије Чолевић Срби у Букурешту - идентитет и Дејана Попова Циркуларни протокол православне српске парохије у Наћвали (1816-1834).

У раду Јордане Марковић Језик научних радова између мултикултуралности и неразумевања говори се о језику научних радова у којима мултикултуралност прераста у неразумевање.

Радови у овоме часопису штампани су на српском, руском, бугарском и енглеском језику, а њихови аутори су из Румуније, Србије, Чешке, Русије и Бугарске. Оно што их обједињује јесте да представљају прилог мултикултуралности на тај начин што осветљавају неки крај, неки народ, неки језик и неке људе тако што нам их приближавају, упознају нас са њима, пружају нам податке које нисмо знали. У њима налазимо анализу нечега што је писмено фиксирано, али поједини од тих радова на овај начин фиксирају и отржу од заборава оно што подлеже одумирању. У нестајању су, пре свега, српски народни обичаји - на тлу Румуније (а свакако и Србиje), а угрожен је и српски народни говор Срба у Румунији. Сваки податак о томе биће драгоцен за историју.

Часопис Исходишта, покренут са намером да промовише мултикултуралност у мултиетничким срединама и/или периферним областима, пре свега кроз приказ материјалне и духовне културе Срба у тим областима, наставља са својом мисијом - по трећи пут доноси богате прилоге, поткрепљене драгоценим подацима. Као и у претходнима, и у овом броју своје место нашли су: историја, обичаји, народни говори, ономастика и бројна друга уметничка, језичка и друштвена поља. Аутори прилога у овоме часопису показали су радозналост, проницљивост и способност за валидну научну 


\section{8}

обраду појава којима се у својим радовима баве. То читаоцу пружа могућност да се упозна са нечим што досад није знао и што може бити инспирација за нове идеје. Радови у овоме часопису пружиће читаоцу могућност да дозна нешто ново и занимљиво. 